\title{
Russia Introduces Integration Examination for Migrants: Some Legal Aspects
}

\author{
Ekaterina Vyacheslavovna Kiseleva ${ }^{1} \&$ Olga Sergeevna Kazhaeva ${ }^{1}$ \\ ${ }^{1}$ Department of International Law, Peoples' Friendship University of Russia, Moscow, Russian Federation \\ Correspondence: Kiseleva E. Viacheslavovna, Room 370, Miklukho-Maklaya str., 6, Moscow, 117198, Russian \\ Federation. Tel: 7-916-246-1003. E-mail: ekaterina.kiseleva.rudn@gmail.com
}

Received: December 20, 2014 Accepted: January 5, 2015 Online Published: February 25, 2015

doi:10.5539/res.v7n3p15

URL: http://dx.doi.org/10.5539/res.v7n3p15

The article is prepared with the support of the Ministry of Education and Science of the Russian Federation in frames of scientific work in 2014 No. 10.9063.2014.

\begin{abstract}
Having a two years' experience in language tests for limited categories of migrants, Russia introduces an examination in the Russian language, history of Russia and the basics of the Russian legal system for a wider list of foreigners from January 1, 2015. The article reflects legal regulation of the examination introduction. Special attention is given to the development of the legal module of the exam up to the present moment.
\end{abstract}

Keywords: migration, legal regulation, integration of migrants, integration test, basics of the Russian legal system for migrants

\section{Introduction}

It is a common knowledge in the XXI century that sustainable development in the countries of the Global North is impossible without migration. At the same time, miscalculations in migration policy may predictably put safety and security of the society at risk. In an effort to have selective and well-governed migration, more and more states pay increasing attention to measures of migrants' integration and integration tests as forming a part of such measures.

For more than a decade, Russia is the second state in the world in terms of number of migrants in its territory. Russia attracts people for work, study, residence, etc. The country shares with Switzerland the third place as a main source of remittances (The State Migration Policy Concept of the Russian Federation for the period up to 2025, 2012).

As many other migrant receiving states, Russia took a path of introducing a range of tests in order to achieve several goals. These goals are to be found in the Concept of the state migration policy in the Russian Federation for the period up to 2015 (The State Migration Policy Concept of the Russian Federation for the period up to 2025, 2012), they are the following: to vary state's approaches to governing migration flows on basis of aims and length of intended stay, social-demographic and professional characteristics of migrants (International migration report, 2012), to create conditions for adaptation and integration of migrants, protection of their rights and freedoms in order to avoid isolation of migrants from the receiving community and of increase of negative attitude towards migrants (International migration report, 2012), to harmonize inter-ethnic relations, strengthen the unity of multiethnic people of the Russian Federation and secure conditions for thepeople's full development (Review of Russian Migration Legislation Changes from December, 2011).

\section{Methods}

At present, there are several types of educational tests for migrants, e.g. language test, integration examination (exam in the Russian language, history of Russia and the basics of the Russian legal system), interview for approving that a person is a native speaker of the Russian language fur the purpose of naturalization. This article is about the integration examination, its organization from the point of law and methodology of preparation. Special attention is paid to the module on the Russian law.

Introduction of the "legal" module into the examination for migrants was initially announced in 2007 (Review of 
Russian Migration Legislation Changes from December, 2011). Since then, the content of this element of the integration exam was a topic of both scientific research and suggestions by the academia (Kashkin, 2013), as well as the issue of public and expert debates.

The exam in the Russian language, history of Russia and the basics of the Russian legal system was officially announced by the Decree of the President of the Russian Federation of May 7, 2012, "On securing inter-ethnic concord". With the aim of harmonizing inter-ethnic relations, strengthening the unity of multiethnic people of the Russian Federation and securing conditions for the people's full development the obligatory examination in the Russian language, history of Russia and the basics of the Russian legal system was introduced for migrant workers, with the exception for high-skilled specialists(Review of Russian Migration Legislation Changes from December, 2011). In pursuance of the Decree, the Ministry of Education and Science of the Russian Federation adopted a draft of the Concept of the examination in the Russian language, history of Russia and the basics of the Russian legal system and requirements for the possession of knowledge of the corresponding disciplines on December 20, 2013 (Introduction the necessary exam in Russian language, history of Russia, the basis of legislation for working migrants, 2012). The Decree itself was adopted on August 29, 2014, and was not officially published as of September 23, 2014.The examination will become obligatory for foreign nationals willing to work in Russia, as well as for those willing to obtain residence permit or a temporary residence permit starting from January 1, 2015. From September 1, 2014, the mentioned categories of migrants will be able to pass the exam, is they so wish.

Introduction of the examination for certain categories of migrants reflects the conceptual approach to adaptation and integration of migrants that can be found in the Concept of the state migration policy in the Russian Federation for the period up to 2015 (Review of Russian Migration Legislation Changes from December, 2011). Strategy of the state national policy of the Russian Federation for the period up to 2015 and other legal acts (Kiseliova\&Kazhayeva, 2014).

The Concept of the state migration policy in the Russian Federation for the period up to 2015 was approved by the Russian President on June 13, 2012. In accordance with paragraph 17 of the Concept "important elements of the state migration policy of the Russian Federation are building conditions for adaptation and integration of migrants, protection of their rights and freedoms, providing for social security (International migration report, 2012). The same paragraph stresses that "the direct result of the absence of state programmes for adaptation and integration is isolation of migrants from the receiving community and growth of the negative attitude towards migrants". The test including the block of legal information is surely suitable for achieving the stated goals. Although civic tests are considered recently to be both measures of migration management and migrants' integration, the latter character of the tests is still present(Goodman, 2010).

The Concept of the state migration policy in the Russian Federation provides also for the principles of state migration policy. Among them we can find "differential approach to governing migration flows on basis of aims and length of the intended stay, social demographic and professional characteristics of migrants" (paragraph 22). For the implementation of the main directions of the state's migration policy there are several objectives set in the document. There are two among them, that relate to the initial goal of "legal" module introduction, they are the following. "Elaboration of differentiated mechanisms of attracting, selecting and using the foreign labour force; promotion of adaptation and integration of migrants, formation of positive interaction between migrants and the receiving society" (paragraph 23). These provisions of the Concept are reflected in the variability of the exam between different categories of migrants. For example, a differentiated passing score for migrant workers, applicants of the temporary residence permit and applicants of the residence permit is under the debate.

Among main directions of the Russia's migration policy we can also see "creating infrastructure for the integration and adaptation of migrant workers, including information and legal support centers and courses in Russian language, history and culture in the countries of migrants' origin and in the regions of Russia having the biggest inflow of migrants" (paragraph 24).

In the Annual President's Address to the Federal Assembly of the Russian Federation of 2012, the Russian President ordered to elaborate a set of measures aimed at implementation of the state's national policy, including measures on social and cultural adaptation of migrants. This resulted, for example, in several paragraphs of the Action Plan for the implementation in 2013-2015 of the Strategy of the state national policy of the Russian Federation for the period up to 2015, approved by the Resolution of the Russia's Government dated July 15, 2013, No. 1226-p.

As it was stated above, in pursuance of the mentioned acts, the Inter-departmental commission on issues of the Russian language of the Ministry of Education and Science of the Russian Federation adopted a draft of the Concept of the examination in the Russian language, history of Russia and the basics of the Russian legal system 
and requirements for the possession of knowledge of the corresponding disciplines on December 20, 2013 (Introduction the necessary exam in Russian language, history of Russia, the basis of legislation for working migrants, 2012). "On the $20^{\text {th }}$ of April, 2014, a draft law No. 161211-6","On amending art. 25.6 of the Federal Law", "On the procedure for entering into and exiting from the territory of the Russian Federation" and the Federal Law "On the legal position of foreign citizens in the Russian Federation"(About the legal status of foreign citizens in the Russian Federation, 2014) was signed by the President of the Russian Federation. The amendments stipulate that certain categories of foreign nationals who applied for an ordinary working visa or for a residence permit, or foreign nationals coming to the Russian Federation in order to pursue labour activities on basis of work permit or a patent without being obliged to have visa will have to undergo verification of their Russian language abilities, knowledge of the history of Russia and of the basics of the Russian legal system. Let us consider some aspects of form and content of the "legal" module.

Currently, the module on the basics of the Russian legal system as an element of the integration examination includes five substantial parts, covering twelve topics, they are (1) foundations of the Constitutional order of Russia (topics on state symbols of Russia, Constitutional order of Russia, human rights and freedoms in Russia (civil and political rights, economic, social and cultural rights)); (2) status of a foreign citizen in the Russian Federation (topics on entering into, stay in and exiting from the territory of Russia, labour law of Russia with special attention to rules on migrant workers' labour activities regulation); (3) practical aspects of life (basics of civil and family law); (4) duties and responsibility of foreign nationals in Russia; (5) interaction with state officials (topics on interaction with Federal Migration Service of Russia, police, State inspection for road traffic safety, tax organs of Russia, as well as with consular offices of the foreigner's state of citizenship).

The list of the topics shows that some of them are rather general, while others are specific and touch upon the questions of rights that migrants have in the territory of Russia and obligations they bear during their stay. Five topics are considered to be a priority, i.e. entering into, stay in and exiting from the territory of Russia, labour law of Russia with special attention to rules on migrant workers' labour activities regulation, duties and responsibility of foreign nationals in Russia, interaction with state officials of Russia.

From the point of goals that were set for elaborators of this part of the integration examination, it is to be noted that the content of the module has two principal aims. A person prepared for the examination acquires knowledge on his or her rights and obligations valid during the stay in the Russian Federation. On the other hand, a prepared candidate becomes aware of the organization of the Russian state and system of legislation that can be helpful and giving the direction even in the search of qualified legal consultation.

Substantially, the initial list of topics was enriched with the elements of civil and family law, with widening of issues of interaction with the Russian state officials (where two topics were created instead of one) and with including the topic of interaction with consular offices of the foreigner's state of citizenship. The last mentioned topic demands a comment.

The module under consideration is entitled "the basics of the Russian legal system". The interaction with consular offices of the foreigner's state of citizenship is generally outside the scope of the national law. However, and here the voices of state organs' representatives, academia, civil society institutes, as well as of NGOs representing the interests of various groups of migrants are in concord, it is equally important for a migrant to know both about duties and rights of Russia towards him/her and about duties and rights of their respective Fatherland. It is sometimes vital to know what acts with legal consequences may be carried out only by their country of citizenship and why these acts are not justiciable through the Russian judicial system. Migrants shall know the circumstances when it is an obligation of Russia to provide them with possibility of communication with consular office, etc.

Examination questions list was also modified by the exclusion of groups of questions that have no practical meaning for migrants, e.g. who is the head of the Federal Migration Service of Russia, or questions referring to categories of migrants left outside the scope of the exam, e.g. applicants for citizenship, highly qualified specialists and others.

The form of the examination module was also transformed due to debates and the results of approbation. Initially, the module included two subtests. The first subtest contained multiple choice questions, the second subtest required a migrant to insert a word or a phrase missing in a given sentence. The second subtest proved to be especially difficult for migrants. As a result it was changed.

Instead of the task to insert a word or a phrase, the amended second subtest required a short answer to an open question, e.g. what legal act governs the issues of crime and punishment in Russia? However, even in this form the second subtest was found to be unsuitable. Some problems are on the surface, e.g. in case of the computer-based testing, the answer was to be marked and wrong when additional space was typed between words or a spelling 
mistake was made. Moreover, a trivially correct answer may be different from the legally correct one.

As a result of expert and public debate the second subtest was entirely excluded. There was, however, made a slight modification in the remaining questions. Some of them were reformulated into the mini-cases, e.g. "You are at the bus stop. A policeman approaches you and asks to show your identity documents. Is he entitled to do so?"

Great effort was also exerted for simplification of the language of the questions and answers. The Russian law stipulates that the language abilities of migrants are evaluated in accordance with the levels of "testing Russian as a foreign language" that is equivalent to the European system of ALTE. The language of laws, however, is specific and full of law-terms. In this respect, a huge work was done in cooperation between lawyers, on the one hand, and philologists and testologists, on the other.

A separate issue is the passing scores. While in the majority of states using civic tests, pass follows correct answers to a qualified number of questions, in Russia it was decided to leave similar rules only to the language part of the exam. The success in module on the basics of the Russian legal system was, firstly, to be declared with 50 per cent plus one question, but further it was left lower. Currently, the discussion is about setting different levels of pass for those wishing only a temporal work and those applying for a temporary residence permit or residence permit. The question when the applicants for citizenship who are now obliged only to prove language abilities will have to pass similar integration examination is yet without any answer at all.

As for the preparatory infrastructure, several aspects are to be mentioned. Generalized requirements to knowledge of the basics of the Russian legal system are governed by the Ministry of Education and Science of the Russian Federation. A detailed description of requirements is awaited to come from the elaborators of the examination tasks, as well as a sample test. A list of about hundred open questions that are combined in form of test questions in the examination tasks, for more than half a year before the introduction of the exam as obligatory, is made available on the web-site of the elaborators, the Russian Test Consortium (uniting four state higher education institutes, i.e. Moscow State University, S.-Petersburg State University, Peoples' Friendship University of Russia and Pushkin State Institute of the Russian Language). The text-book for preparation to this module of the exam has already been published. A wide campaign of raising public awareness of the implementation of the exam is being carried out by the Consortium for already a year both in Russia and abroad.

\section{Results}

So here we are three month prior to the enforcement of the integration examination (exam in the Russian language, history of Russia and the basics of the Russian legal system). The approbation of the examination was successful. Let us wish that the exam itself is successful, too. In Russia, there are hardly any issues of human rights or discriminatory effect of the exam raised, as they are in some European states (Semenova, 2012), however, it will be interesting and necessary to assess, at least, the effect of the exam as a measure of reaching the goals stated in the Concept of the state migration policy in the Russian Federation for the period up to 2015 that were cited at the beginning of this material.

\section{References}

Facts and figures on global migration, Global estimates and trends. (2014). Retrieved from http://www.iom.sk/en/about-migration/facts-figures

Goodman, S. W. (2010). Naturalisation Policies in Europe: Exploring Patterns of Inclusion and Exclusion. Florence: $\quad$ European University Institute. Retrieved http://eudo-citizenship.eu/docs/7-Naturalisation\%20Policies\%20in\%20Europe.pdf

Bauboeck, R., \&Joppke, C. (Eds.) (2010). How liberal are citizenship tests? Florence: European University Institute.

International migration report.(2012). from http://www.hse.ru/data/2013/04/18/1297847641/INTENATIONAL\%20MIGRATION\%20IN\%20\%20RUSS IA.SOPEMI\%20REPORT\%202012.pdf

Introduction the necessary exam in Russian language, history of Russia, the basis of legislation for working migrants. (2012). Retrieved from http://government.ru/orders/9797

Kashkin, S. V. (2013). Concept exam on the basics of legislation of the Russian Federation for working migrants.LexRussica, 10,1094-1097.

Kiseliova, E. V., \&Kazhayeva, O. S. (2014).The legal module of integrative exam for migrants in view of Russian national migrational policy.Zakonipravo, 10. 
Million international migrants living abroad worldwide-New UN global migration statistics reveal. (2014). Retrieved from http://esa.un.org/unmigration/wallchart2013.htm

Nemytina, M. V., \&Podmarev, A. A. (2013).Fundamentals of legislation of the Russian Federation: Training methodology of exam's preparation for working migrants. Moscow: Peoples' Friendship University of Russia.

Review of Russian Migration Legislation Changes from December. (2011). Retrieved from http://www.amcham.ru/_images/upload/3\%20Eng_Review_Russian\%20Migration\%20Legislation\%20Cha nges_Dec,\%202011-June,\%202012_LEVINE\%20Bridge.pdf

Strik, T. (2013).Integration tests: Helping or hindering integration. Retrieved from http://www.assembly.coe.int/nw/xml/XRef/X2H-Xref ViewPDF.asp?FileID=19772\&lang=en

Semenova, N. S. (2012). Education as a factor of keeping peace in multi-ethnic society.Herald of Eurasian national university n.a. Gumilev, 1.

Semenova, N. S. (2013).The role of education in the field of human rights in prevention of cross national conflicts. Moscow: Yurist.

The State Migration Policy Concept of the Russian Federation for the period up to 2025. (2012). Retrieved from http://www.confidencegroup.ru/news.aspx?sid=71\&id=183\&backurl=/Default.aspx?sid\%3D71\&language= en-US

\section{Copyrights}

Copyrightforthisarticleisretainedbytheauthor(s), withfirstpublicationrightsgrantedtothejournal.

Thisisanopen-accessarticledistributedunderthetermsandconditionsoftheCreativeCommonsAttributionlicense(http: //creativecommons.org/licenses/by/3.0/). 